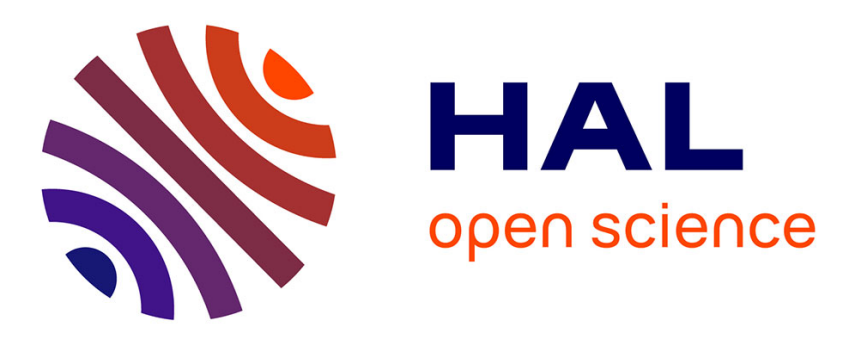

\title{
The contribution of rock fragments to the available water content of stony soils: proposition of new pedotransfer functions
}

Marion Tetegan, Bernard B. Nicoullaud, Denis Baize, Alain Bouthier, Isabelle I. Cousin

\section{To cite this version:}

Marion Tetegan, Bernard B. Nicoullaud, Denis Baize, Alain Bouthier, Isabelle I. Cousin. The contribution of rock fragments to the available water content of stony soils: proposition of new pedotransfer functions. Geoderma, 2011, 165 (1), pp.40-49. 10.1016/j.geoderma.2011.07.001 . hal-02650585

\section{HAL Id: hal-02650585 \\ https://hal.inrae.fr/hal-02650585}

Submitted on 29 May 2020

HAL is a multi-disciplinary open access archive for the deposit and dissemination of scientific research documents, whether they are published or not. The documents may come from teaching and research institutions in France or abroad, or from public or private research centers.
L'archive ouverte pluridisciplinaire HAL, est destinée au dépôt et à la diffusion de documents scientifiques de niveau recherche, publiés ou non, émanant des établissements d'enseignement et de recherche français ou étrangers, des laboratoires publics ou privés. 
Version définitive du manuscrit publié dans / Final version of the manuscript published in :

Geoderma, 165(1), 40-45

The contribution of rock fragments to the available water content of stony soils: proposition of new pedotransfer functions

\author{
M. Tetegan a, b ${ }^{\text {, B. Nicoullaud }}{ }^{\text {a }}$, D. Baize ${ }^{\text {a }}$, A. Bouthier ${ }^{\text {b }}$, I. Cousin ${ }^{\text {a }}$ \\ a Institut National de la Recherche Agronomique, UR 0272 Science du Sol, 2163 Avenue de la Pomme de \\ Pin, CS 40001 Ardon 45075 Orléans Cedex 2 - France \\ b ARVALIS - Institut du Végétal, Domaine expérimental du Magneraud 17700 Saint Pierre d'Amilly - \\ France
}

\begin{abstract}
The contribution of rock fragments to the soil available water content (SAWC) of stony soil has been quantified by measurements of bulk density and gravimetric water content at different water potentials on rock fragments of different lithologies: flints, cherts, chalks, gaizes and limestones. More than 1000 pebbles $(2 \mathrm{~cm}<$ equivalent diameter of the rock fragment $<5 \mathrm{~cm}$ ) have been sampled in stony soils developed from each of the five lithologies. We demonstrated that the water content at saturation of the studied pebbles was equal to the water content at $-100 \mathrm{hPa}$ and to the water content at field capacity. A linear relationship between the water content at $-100 \mathrm{hPa}$ and at $-15840 \mathrm{hPa}$ enabled to derive a simple pedotransfer function to determine the available water content of the rock fragments. We also proposed a second simple pedotransfer function, which expresses the available water content from the dry bulk density of the rock fragments only. A simulation at the horizon scale for a loamy-clay stony horizon showed that the SAWC could be strongly misjudged when the rock fragments were not taken into account: for a stony horizon containing $30 \%$ of pebbles, the SAWC is underestimated by $5 \%$ for chert pebbles and by $33 \%$ for chalk pebbles.
\end{abstract}


Version définitive du manuscrit publié dans / Final version of the manuscript published in :

Geoderma, 165(1), 40-45

\section{Introduction}

Stony soils are soils containing over $35 \%$ or $40 \%$ in volume of soil particles larger than $2 \mathrm{~mm}$ : the rock fragments (FAO, 2006; Soil Survey Staff, 2010). These soils are composed of several fractions (Corti et al., 1998): fine earth (particle diameter $<2 \mathrm{~mm}$ ), gravels $(2<$ particle diameter $<20 \mathrm{~mm})$, pebbles $(20<$ particle diameter $<50 \mathrm{~mm})$, stones $(50<$ particle diameter $<200 \mathrm{~mm}$ ) and blocks (particle diameter $>200 \mathrm{~mm}$ ). The stony soils, often shallow, cover about $30 \%$ of areas of Western Europe, and up to $60 \%$ in Mediterranean areas (Poesen and Lavee, 1994). The wide distribution of this type of soil generates interest in its functioning, but the characterization of stony soils remains difficult. Since the founding works of Berger (1976), Coile (1953) and Gras (1994), the rock fragments, that we define here as the "stony phase", are usually recognised as non inert and are taken into account when some physical or chemical properties of these soils are characterised.

As far as the hydraulic functioning of soil is concerned, the rock fragments may influence the water storage (Cousin et al., 2003; Ugolini et al., 1998), the infiltration rate (Brakensiek and Rawls, 1994; Corey and Kemper, 1968; Grant and Struchtemeyer, 1959) and the surface evaporation regime (Groenevelt et al., 1989; Jury and Bellantuoni, 1976; Kemper et al., 1994; Koon et al., 1970; Poesen and Lavee, 1994).

According to Beatens et al. (2009), the water content of a soil horizon usually decreases when the rock fragments content increases (Baetens et al., 2009; Cousin et al., 2003; Poesen and Bunte, 1996), but the horizon water content depends on i) the nature of the rock fragments, ii) their position in the soil (Childs and Flint, 1990) and their degree of weathering: Poesen and Lavee (1994) demonstrated that rock fragments water content may vary according to their weathering, the smallest rock fragments - supposed to be the most altered - being able to absorb a higher quantity of water. In some cases, rock fragments can contribute to a proportion of a quarter of the total available water content (Fies et al., 2002).

The presence of rock fragments usually results in a decrease in the infiltration rate (Childs and Flint, 1990; Ma et al., 2010; Ma and Shao, 2008) since they reduce the surface available for the flow transport in the soil. Nevertheless, rock fragments can also increase the infiltration rate (Ravina and Magier, 1984), by the creation of preferential pathways at the fine earth-stone interface (Urbanek and Shakesby, 2009; Zhou et al., 2009), the latter being active only at high water contents (Verbist et al., 2009). The evaporation rate decreases as the amount of rock fragment increases if soils are in wet conditions. On the contrary, on a dry soil, the fine earth becomes wet first when it rains, and the rate of evaporation is positively correlated with the content of rock fragments (Coutadeur et al., 2000; Van Wesemael et al., 1996).

All the studies cited above describe the evolution of the soil hydric functioning when the soil comprises some rock fragments. Other recent works have demonstrated the role of rock fragments on the soil hydric properties, both the water retention curve and the saturated 
Version définitive du manuscrit publié dans / Final version of the manuscript published in : Geoderma, 165(1), 40-45

and unsaturated hydraulic conductivity, by numerical simulations (Ma and Shao, 2008) or experiments. The evolution of the hydraulic conductivity in the presence of rock fragments has been discussed from in situ experiments: Verbist et al., (2009) showed that the unsaturated hydraulic conductivity could decrease in soils with rock fragments whereas the saturated hydraulic conductivity increased. The latter was confirmed by laboratory experiments on remoulded samples (Ma et al., 2010; Urbanek and Shakesby, 2009; Zhou et al., 2009). Baetens et al. (2009) have demonstrated the decrease of water content at a given water potential by in situ infiltrometer experiments and laboratory measurements of the water retention curve on large undisturbed samples. Nevertheless, as far as the water retention curve is concerned, the determination of the water content at a given potential on a heterogeneous soil can be calculated by independent measurements on each phase, i.e., for stony soils, by independent measurements of the water content of the fine earth and of the rock fragments. In this paper, we will develop this approach: we will first characterise some physical properties, and especially the gravimetric water content, of rock fragments sampled in soils from different regions of France. These data will be used to propose some pedotransfer functions to estimate the available water content of rock fragments in stony soils. These functions will then allow us to calculate the available water content of a theoretical stony soil profile.

\section{Materials and methods}

\subsection{Sampling and characterisation of samples}

The rock fragments were sampled in soils developed over sedimentary rocks, on different locations, mainly in the central part of France (Fig 1). They were of the following lithologies: gaize, chalk, chert, flint, and limestone. Gaize is a non-common siliceous rock of sedimentary origin, fine grained and porous. This rock is mainly observed in France and in Belgium (Foucault and Raoult, 2001; Michel et al., 2004). These major lithological classes were divided into sub-classes described in Table 1. These five lithologies were chosen because they are well represented in French agricultural regions. Limestone was divided into four subclasses and flint was divided into two groups, according to their degree of weathering.

For practical reasons due to sampling, only the "pebble" fraction $(20 \mathrm{~mm}<$ rock fragment diameter $<$ to $50 \mathrm{~mm})$ and the "gravel" fraction $(4 \mathrm{~mm}<$ rock fragment diameter $<$ to $20 \mathrm{~mm}$ ) were analysed. Pebbles and gravels were sampled randomly by hand, mainly in the Ap horizon $(0-30 \mathrm{~cm})$, and $30 \%$ of pebbles were taken in the lower horizons. Thus, 1594 pebbles, collected from 114 soil horizons from different geological origins were analysed, as well as 270 gravels, collected in soil horizons containing flint or limestone. Most of the samples were collected when the soil was at field capacity. To reduce water loss by evaporation, the samples were kept in plastic bags sealed with a rubber band, and stored at $4^{\circ} \mathrm{C}$ until analyses. Just before experiments, the rock fragments were carefully and gently brushed to remove them of their fine earth coatings. 


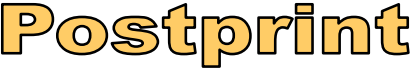

Version définitive du manuscrit publié dans / Final version of the manuscript published in : Geoderma, 165(1), 40-45

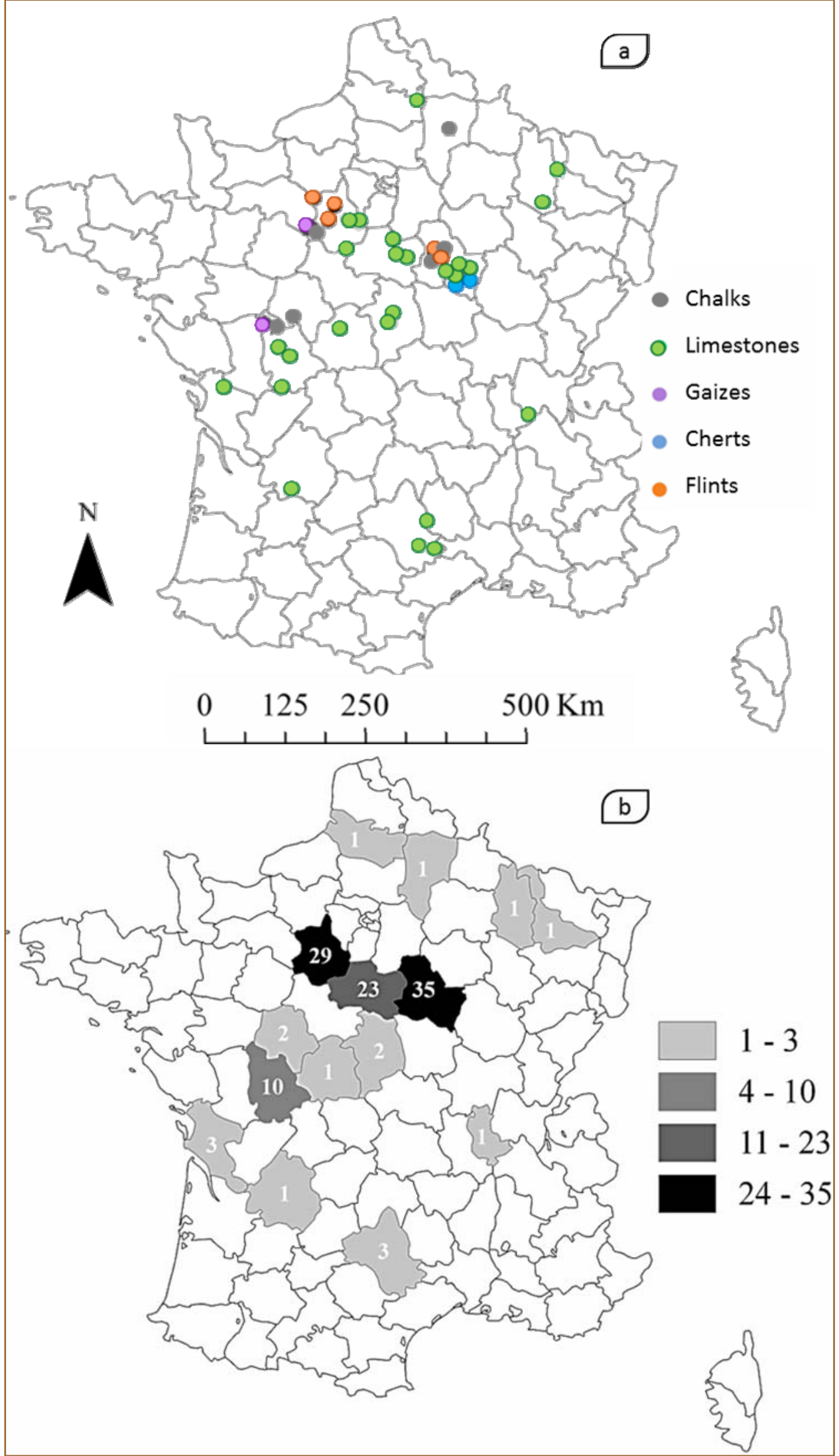

Figure 1: Location of sampling sites: a) lithological classes of the studied rock fragments, b) number of horizons sampled per French administration regions 


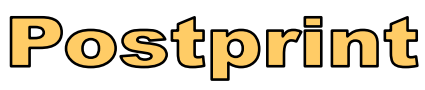

Version définitive du manuscrit publié dans / Final version of the manuscript published in :

Geoderma, 165(1), 40-45

Table 1: Brief presentation of lithological classes and sub-classes of rock fragments, with additional informations about geology, soils, and sampling sites.

\begin{tabular}{|c|c|c|c|c|c|c|c|}
\hline $\begin{array}{c}\text { Major lithological } \\
\text { classes }\end{array}$ & $\begin{array}{c}\text { Lithological } \\
\text { sub-classes }\end{array}$ & $\begin{array}{c}\text { Number of } \\
\text { sites }\end{array}$ & $\begin{array}{c}\text { Number of } \\
\text { rock fragments }\end{array}$ & $\begin{array}{c}\text { Non calcareous residues } \\
\text { in rock fragments } \\
\end{array}$ & Stratigraphy & \begin{tabular}{|c|} 
Soils or \\
Parent material \\
\end{tabular} & $\begin{array}{c}\begin{array}{c}\text { French Natural } \\
\text { regions }\end{array} \\
\end{array}$ \\
\hline \multirow{2}{*}{ Chalks } & pure & 9 & 180 & 1 to $6 \%$ & Turonian, Senonian & Chalky soils & Champagne, Jovinien \\
\hline & clayey & 3 & 36 & 13 to $30 \%$ & Cenomanian & Shallow clayey soils & Jovinien \\
\hline \multirow{4}{*}{ Limestones } & pure and hard & 32 & 769 & $<4 \%$ & $\begin{array}{l}\text { Middle and Upper } \\
\text { Jurassic, Miocene }\end{array}$ & $\begin{array}{l}\text { Diverse calcareous soils, more or } \\
\text { less deep }\end{array}$ & $\begin{array}{l}\text { Lower Burgundy, Beauce, } \\
\text { Berry, Poitou, Charentes, Causses }\end{array}$ \\
\hline & chalky & 6 & 90 & n.d. & Lower Kimmeridgian & Calcareous silty slope deposits & \multirow{3}{*}{ Lower Burgundy } \\
\hline & oolitic & 1 & 15 & n.d. & Bathonian & Calcareous sandy slope deposits & \\
\hline & marly & 4 & 120 & 5 to $15 \%$ & Lower Oxfordian & Shallow calcareous soils & \\
\hline Gaizes & & 8 & 128 & & Turonian, Cenomanian & Clayey and silty soils & Perche, Loudunais \\
\hline Cherts & & 3 & 54 & & Callovian & $\begin{array}{l}\text { Acidic deep soils developed in } \\
\text { "clay with cherts" } \\
\end{array}$ & Lower Burgundy \\
\hline \multirow{4}{*}{ Flints } & "flint 1" & 3 & \multirow[t]{3}{*}{178} & & Turonian & Chalky soils & Jovinien \\
\hline & & 1 & & & Miocene & Soils developed in "clay with flints" & \multirow[t]{3}{*}{ Thymerais, Jovinien } \\
\hline & & 4 & & & Pleistocene & Silty deposits with flints & \\
\hline & "flint 2" & 2 & 24 & & Eocene & Clayey-stony detrital deposits & \\
\hline
\end{tabular}


Version définitive du manuscrit publié dans / Final version of the manuscript published in :

Geoderma, 165(1), 40-45

\subsection{Characterisation of the structural properties of the rock fragments}

The physical properties of each pebble were characterized by measurements of dry bulk density, solid density, and by calculation of the void ratio of the sample. For measurements of bulk density and solid density, the experiments were performed on sets of 12 pebbles by horizon. Tests were conducted on measurements of 30 samples, 15 samples and 12 samples. For these three sets of samples, we obtained the same mean and median values. We then concluded that "12" was the minimum number of samples to be analyzed to estimate the rock fragments physical properties within a soil horizon. The dry bulk density, $d\left(\mathrm{~g} . \mathrm{cm}^{-3}\right)$, was determined by the Archimedes' displacement method using kerosene (Monnier et al., 1973) and the solid density, $D\left(\mathrm{~g} \cdot \mathrm{cm}^{-3}\right)$, by a gas pycnometer (Micromeritics Accupyc 1340).

\subsection{Characterisation of the hydric properties of the rock fragments}

When the pebbles were collected at field capacity, we determined the gravimetric water content $(W$ in $\mathrm{g} / 100 \mathrm{~g})$ at field capacity $\left(W_{f c}\right)$. Whatever their water content at sampling, the pebbles were first saturated by capillarity during seven days and we determined the water content at saturation $\left(W_{\text {sat }}\right)$. We also determined the gravimetric water content after the pebbles were equilibrated at $-100 \mathrm{hPa}\left(W_{-100}\right)$ and $-15840 \mathrm{hPa}\left(W_{-15840}=\right.$ water content at wilting point). These gravimetric water contents $\left(W_{-100}\right.$ and $\left.W_{-15840}\right)$ were measured on a pressure membrane or plate apparatus (Klute, 1986). After saturation by capillarity, the pebbles were placed on a paste of saturated kaolinite $(<2 \mu \mathrm{m})$ to obtain a sufficient hydraulic continuity between them and the pressure membrane or pressure plate. After one week of equilibrium in pressure cells, the gravimetric water content was measured (Bruand et al., 1996). The available water content of each pebble was calculated by using the difference between the water content at field capacity and the water content at wilting point.

\section{$2.4 \quad$ Statistical analysis}

Relationships between the measured parameters $\left(D, d, W_{f c}, W_{\text {sat }}, W_{-100}, W_{-15840}\right)$ were established by linear regression models. To discuss the goodness of fit and validity of the relationships, we randomly selected $5 \%, 10 \%$ and $20 \%$ of the data of our database. The linear relationships were established on the remaining dataset and these samples were used for validation. The coefficients of determination obtained on the three sets of validation were compared with those obtained on the set of calibration to check the stability of the relationships.

For the relationships linking $W_{-100}$ and $d$, the relationship linking $W_{-15840}$ and $W_{-100}$, and the relationships linking $W_{-15840}$ and $d$, two types of equations were calculated: a general one where all the major lithologies of rock fragments were taken into account, and other specific ones for each major lithologies of rock fragments. The general and the specific relationships were compared by a Student test.

All statistical tests were performed using the Xlstat software. 


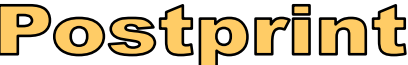

Version définitive du manuscrit publié dans / Final version of the manuscript published in :

Geoderma, 165(1), 40-45

\section{Results}

\subsection{The structural characteristics of pebbles and gravels}

The physical properties of pebbles varied according to their lithology (Fig.2). Results showed that the bulk density of pebbles varied within a single lithological class of pebble (Fig. 2a). Except for the gaize, the mean and the median are slightly different, indicating which shows a slight asymmetrical distribution of values. The bulk density depended on the

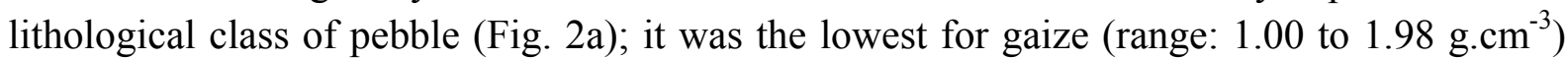
and the highest for limestone (1.5 to $\left.2.72 \mathrm{~g} . \mathrm{cm}^{-3}\right)$ and flint $\left(1.51\right.$ to $\left.2.60 \mathrm{~g} . \mathrm{cm}^{-3}\right)$, and follow the order: $d_{\text {limestone }} \geq d_{\text {flint }} \geq d_{\text {chert }}>d_{\text {chalk }}>d_{\text {gaize. }}$. The same sequence was found for the solid density (Fig. 2b). Within a lithologic class, the solid density was quite stable especially for limestone $\left(\right.$ mean $=$ median $\left.=2.71 \mathrm{~g} \mathrm{~cm}^{-3}\right)$, chert $\left(\right.$ mean $=$ median $\left.=2.63 \mathrm{~g} \mathrm{~cm}^{-3}\right)$ and flint $\left(\right.$ mean $=$ median $\left.=2.62 \mathrm{~g} \mathrm{~cm}^{-3}\right)$. For chalk and gaize, the solid density was variable and varied from 2.45 to $2.78 \mathrm{~g} \mathrm{~cm}^{-3}$ for chalk and from 2.29 to $2.44 \mathrm{~g} \mathrm{~cm}^{-3}$ for gaize.

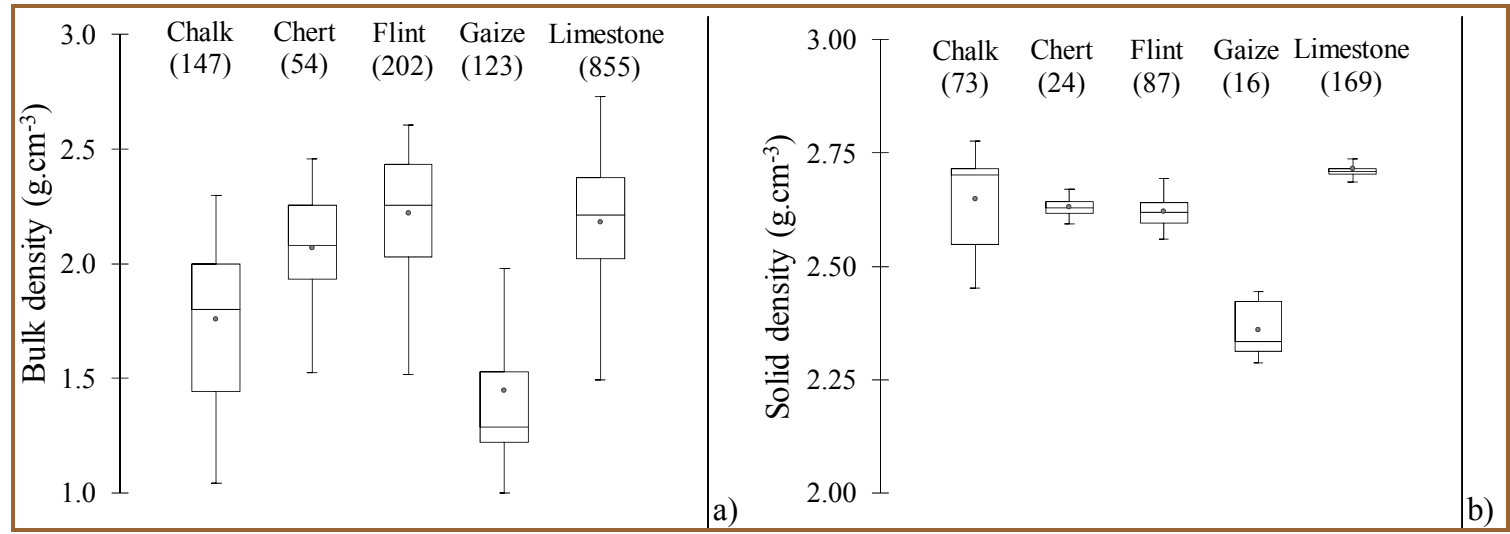

Figure 2: Boxplots representing the range of: a) bulk density, b) solid density for each lithological class of rock fragment. The sample number is in brackets. The upper and lower box boundaries indicate the 75 th and 25 th percentiles, respectively.

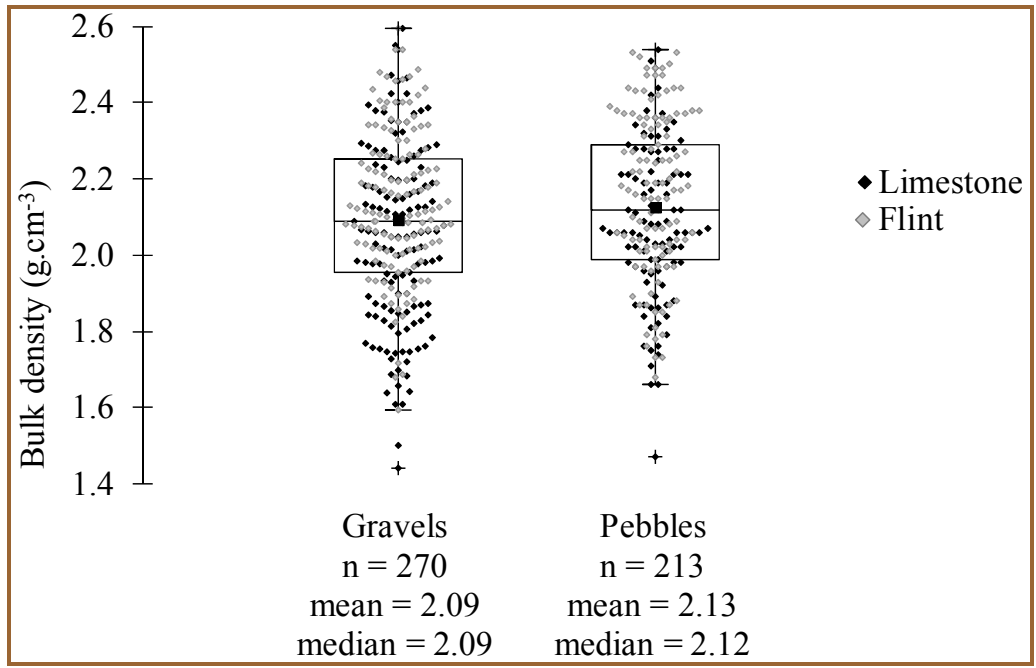

Figure 3: Boxplots representing the range of bulk density by size of rock fragments (gravels at left and pebbles at right). $n$ is the sample number. The upper and lower box boundaries indicate the 75th and 25 th percentiles, respectively. 
Version définitive du manuscrit publié dans / Final version of the manuscript published in :

Geoderma, 165(1), 40-45

On flint and limestone, measurements of bulk density were performed both on gravels and pebbles, collected at the same locations for each lithological class of rock fragment. Figure 3 shows that the ranges of dry bulk density of gravels were similar to that of pebbles.

\subsection{The hydraulic properties of pebbles}

According to their water content at field capacity $\left(W_{f_{c}}\right)$, samples can be ranked as follows (Figure $4 \mathrm{a})$ : gaize $($ mean $=31 \mathrm{~g} / 100 \mathrm{~g})>$ chalk $($ mean $=21 \mathrm{~g} / 100 \mathrm{~g})>$ chert $($ mean $=$ $13 \mathrm{~g} / 100 \mathrm{~g})>$ limestone $($ mean $=9 \mathrm{~g} / 100 \mathrm{~g})>$ flint $($ mean $=6 \mathrm{~g} / 100 \mathrm{~g})$. Some of pebbles showed relatively high water content at field capacity (with values up to $60 \mathrm{~g} / 100 \mathrm{~g}$ for the gaize).

The same sequence among lithology was observed for water content at $-100 \mathrm{hPa}\left(W_{-100}\right)$ and at saturation $\left(W_{\text {sat }}\right)$ (Fig. $4 \mathrm{~b}$ and $\left.4 \mathrm{c}\right)$. Finally, the water content at $-15840 \mathrm{hPa}\left(W_{-15840}\right)$ ranged from values near 0 to $30 \mathrm{~g} / 100 \mathrm{~g}$ : the lowest water contents at wilting point were recorded for limestone, whereas the highest ones $(36 \mathrm{~g} / 100 \mathrm{~g})$ were recorded for gaize.

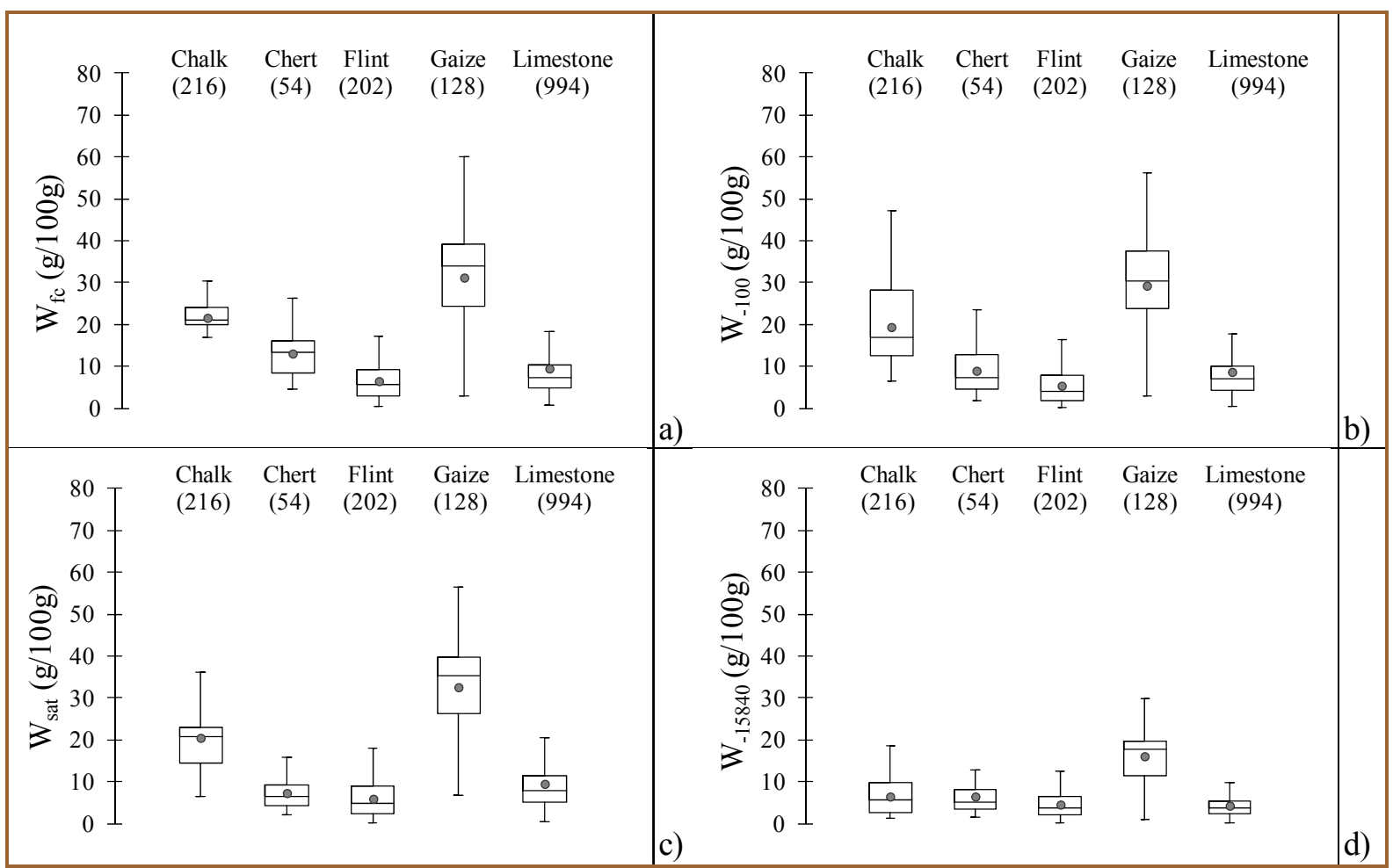

Figure 4: Boxplots representing the range of: a) Water content at field capacity $\left(W_{\text {fc }}\right)$, b) Water content after an equilibrium at $\mathbf{- 1 0 0 h P a}\left(W_{-100}\right)$, c) Water content after saturation $\left(W_{\text {sat }}\right)$, d) Water content after an equilibrium at $-15840 \mathrm{hPa}\left(\mathrm{W}_{-15840}\right)$, for each lithological class of the studied pebbles the sample number is in brackets. The upper and lower box boundaries indicate the 75 th and 25 th percentiles, respectively.

Based on the gravimetric water contents, the following three relationships between water contents values can be demonstrated:

1) The water content at field capacity $\left(W_{f_{c}}\right)$ was very close to the water content at -100 $\mathrm{hPa}\left(W_{-100}\right)$ and the following relationship can be demonstrated (Fig. 5): 


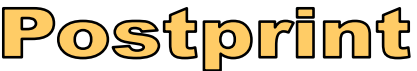

Version définitive du manuscrit publié dans / Final version of the manuscript published in :

Geoderma, 165(1), 40-45

$W_{f c} \approx a W_{-100}$

The value of $a$ was here equal to 1.06, which is really close to 1, and will be considered equal to 1 in the following.

To examine the stability of this relationship, we randomly selected $5 \%, 10 \%$ and $20 \%$ of the samples of our database and calculated again the equation Eq. (1) relationship. The determination coefficient was unchanged at 0.98 , which proved its stability.

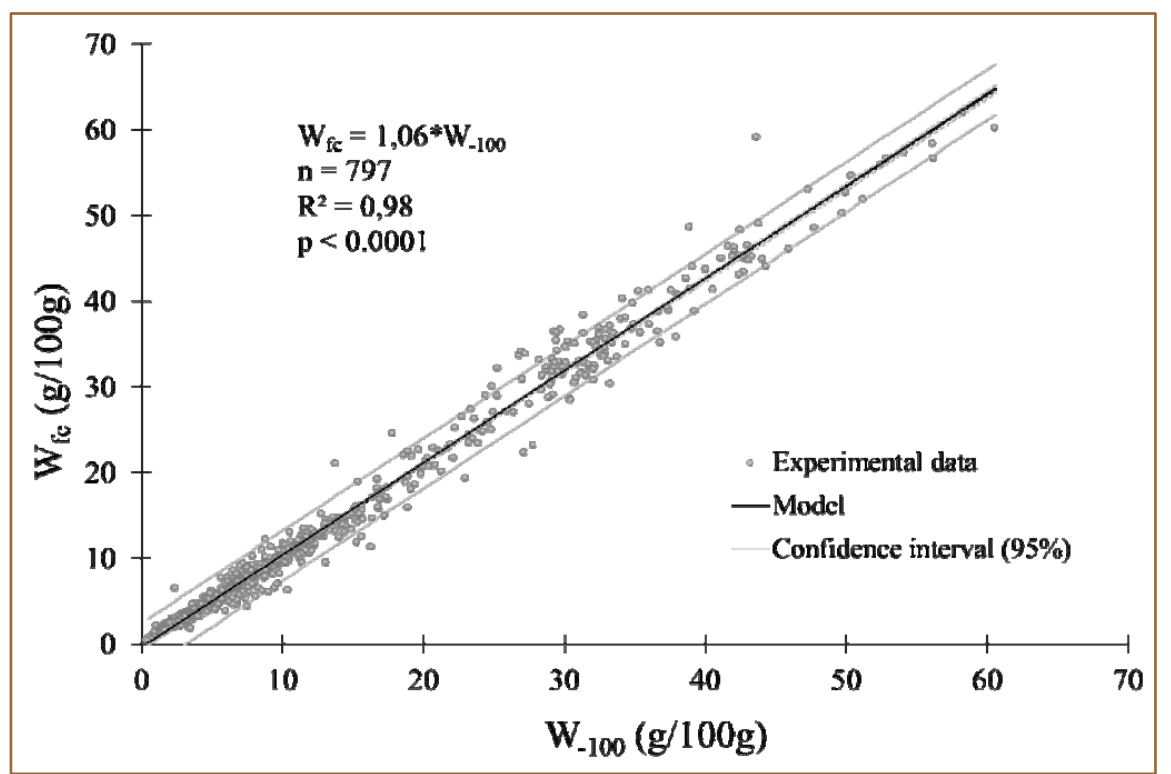

Figure 5: Relationship between water content at $-100 \mathrm{hPa}\left(\mathrm{W}_{-100}\right)$ and at field capacity $\left(\mathrm{W}_{\mathrm{fc}}\right)$ for all pebbles lithological classes. $\mathbf{R}^{2}$ is the determination coefficient and $\mathbf{n}$ is the number of samples analysed.

2) The water content at saturation $\left(W_{\text {sat }}\right)$ was very close to the water content at $-100 \mathrm{hPa}$ $\left(W_{-100}\right)$ and the following relationship can be demonstrated (Fig. 6):

$W_{\text {sat }} \approx b W_{-100}$

The value of $b$ was equal to 1.07 , which is really close to 1 , and will be considered equal to 1 in the following.

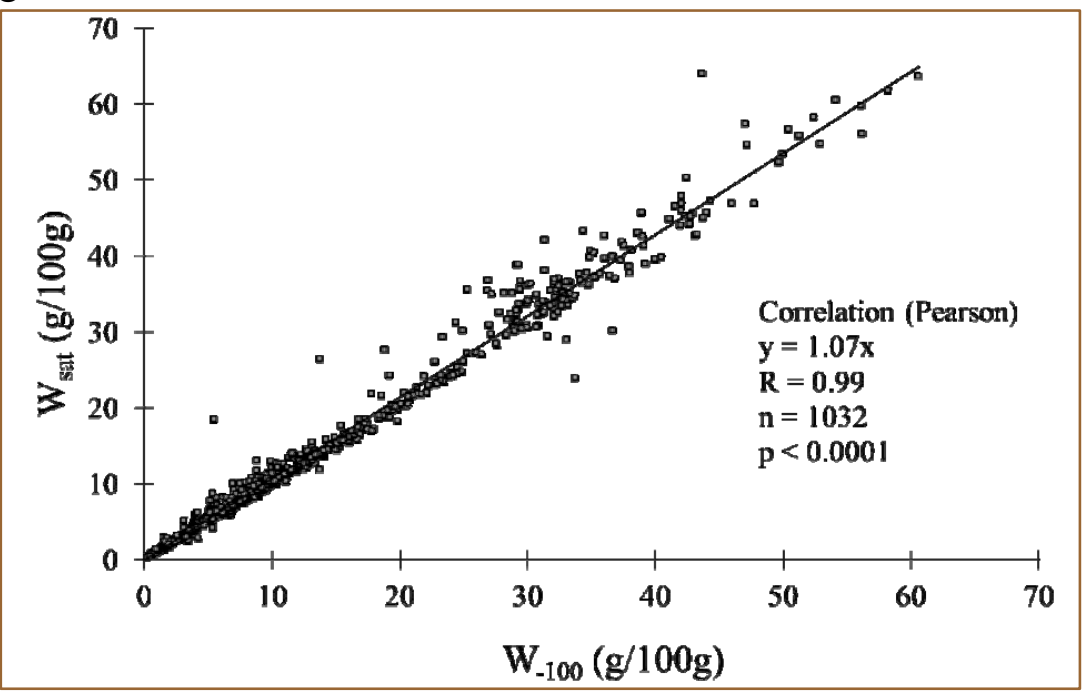




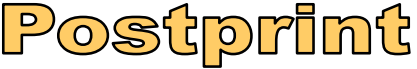

Version définitive du manuscrit publié dans / Final version of the manuscript published in :

Geoderma, 165(1), 40-45

Figure 6: Relationship between water content at saturation $\left(\mathrm{W}_{\text {sat }}\right)$ and at $-100 \mathrm{hPa}\left(\mathrm{W}_{-100}\right)$ for all pebbles lithological classes.

3) We also demonstrated a linear relationship between the gravimetric water content at wilting point $\left(W_{-15840}\right)$ and the gravimetric water content at $-100 \mathrm{hPa}\left(W_{-100}\right)$ (Fig. 7$)$ :

$W_{-15840} \approx c W_{-100}+c^{\prime}$

The $c$ and $c$ ' fitting parameters depended on the lithology of the pebbles, resulting in specific relationships per lithology of rock fragments. For these latter relationships, the coefficients of determination differed considerably among lithologies, with the lowest values in limestone and chalk. A similar linear relationship also exists when all the pebbles from all lithologies were mixed (Fig. 7):

$W_{-15840} \approx j W_{-100}+j^{\prime}$

where $j$ was equal to 0.47 and $j$ ' was equal to 0.64 . To examine the stability of this relationship, we randomly selected $5 \%, 10 \%$ and $20 \%$ of the samples of our database and calculated again the equation Eq. (4). The determination coefficient was unchanged at 0.78 , which proved the stability of the equation Eq. (4).

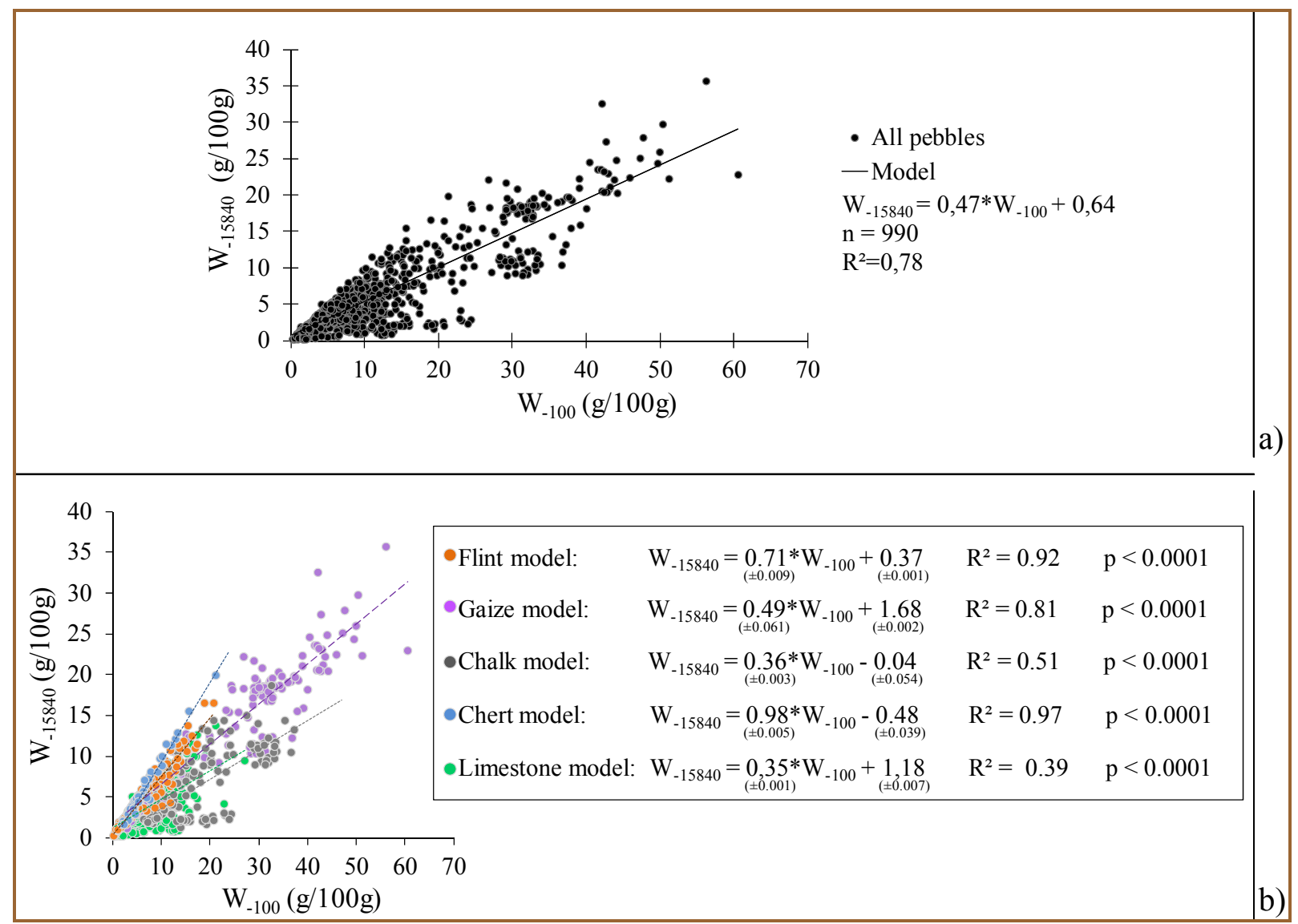

Figure 7: Relationship between water content at $-15840 \mathrm{hPa}(\mathrm{W}-15840)$ and at $-100 \mathrm{hPa}(\mathrm{W}-100)$. a) General relationship. b) Specific relationships for each pebbles lithological class. $R 2$ is the determination coefficient and $\boldsymbol{n}$ is the number of samples analysed. 


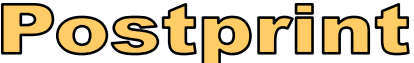

Version définitive du manuscrit publié dans / Final version of the manuscript published in :

Geoderma, 165(1), 40-45

The two types of relationships (the specific ones per lithology of rock fragments and the general one) were then compared to examine if the $j$ coefficient (respectively the $j$ ' coefficient) could be used instead of the $c$ coefficient (respectively $c$ ' coefficient). By using Student tests, we demonstrated that specific relationships are all different from the general relationship. Both $c$ and $c^{\prime}$ coefficients can be replaced by $j$ and $j$ ' coefficients for a rough estimation of the gravimetric water content at wilting point, for example, when a precise determination of the lithological class of rock fragments is not available.

Hence: i) the gravimetric water content at wilting point $\left(W_{-15840}\right)$, could be estimated from the gravimetric water content at $-100 \mathrm{hPa}\left(W_{-100}\right)$ and ii) the gravimetric water content at field capacity $\left(W_{f_{c}}\right)$, at saturation $\left(W_{\text {sat }}\right)$, and at $-100 \mathrm{hPa}\left(W_{-100}\right)$ were equal. This result is consistent with experimental data obtained by Baetens et al. (2009), who demonstrated that rock fragments were saturated down to a water potential equal to $-100 \mathrm{hPa}$.

\section{Discussion}

\subsection{Estimation of the available water content of rock fragments from stony soils}

The best method to assess the available water content (AWC, in $\mathrm{g} / 100 \mathrm{~g}$ ) of the pebbles forming stony soils would be to perform measurements of the water content of pebbles at field capacity and the water content of pebbles at wilting point, and then calculate the difference. Nevertheless, from the preceding results, we can derive a simple pedotransfer function that allows calculating the AWC. By knowing equations Eq. (1), Eq. (2) and Eq. (4), the AWC of rock fragments can be expressed as:

$A W C \approx \xi W_{\text {sat }}+\varsigma \approx \xi W_{f c}+\varsigma \approx \xi W_{-100}+\varsigma$

where $\xi$ and $\varsigma$ are parameters whose values depend of the lithology of the pebbles (Table 2). The parameter $\xi$ varies from 0.70 (for chalk) to 0.08 (for chert). The proposed method is more robust for flint, chert and gaize, than for chalk and limestone, because the determination coefficient of the equation Eq. (4) was lower for these two lithologies of rock fragments (Fig. 7b). Chalk exhibits a high AWC, which is consistent with previous observations by Baillif (1978) and Vachier et al. (1979). On the contrary, flint have a low AWC, but the latter is not close to zero, as stated by Gras and Monnier (1963).

Table 2: The fitting parameters $\xi$ and $\varsigma$ of the equation (Eq. 1.5).

\begin{tabular}{l|c|c|cc|cc}
\hline \multicolumn{2}{c|}{ Pebbles } & \multicolumn{2}{c|}{$\xi$} & \multicolumn{2}{c}{$\varsigma$} \\
\hline Type & $\mathrm{n}$ & $\mathrm{R}^{2}$ & value & standard error & value & standard error \\
\hline Flint & 202 & 0.92 & 0.35 & \pm 0.0090 & -0.37 & \pm 0.0030 \\
Gaize & 127 & 0.81 & 0.57 & \pm 0.0610 & -1.68 & \pm 0.0034 \\
Chalk & 147 & 0.51 & 0.70 & \pm 0.0030 & 0.04 & \pm 0.0540 \\
Chert & 53 & 0.97 & 0.08 & \pm 0.0050 & 0.48 & \pm 0.0391 \\
Limestone & 530 & 0.39 & 0.71 & \pm 0.0010 & -1.18 & \pm 0.0075 \\
All & 1059 & 0.78 & 0.59 & \pm 0.0004 & -0.64 & \pm 0.0049 \\
\hline
\end{tabular}




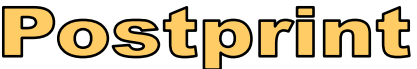

Version définitive du manuscrit publié dans / Final version of the manuscript published in :

Geoderma, 165(1), 40-45

4.2 Links between the hydraulic properties of rock fragments and their bulk density

The following relationships between gravimetric water content at different water potentials and bulk density $(d)$ can be demonstrated:

Erreur ! Signet non défini. $W_{-100}=a_{1} \ln (d)+b_{1}$

(Eq. 6)

$W_{-15840}=a_{2} \ln (d)+b_{2}$

where $a_{1}, a_{2}, b_{1}$ and $b_{2}$ are fitting parameters whose values depend on the lithology of the pebbles (specific relationships) or do not depend on the lithology of the pebbles (general relationship) (Figs. 8 and 9). The determination coefficients for equation (Eq. 6) were higher than those observed for equation (Eq. 7), especially for chalk and limestone.

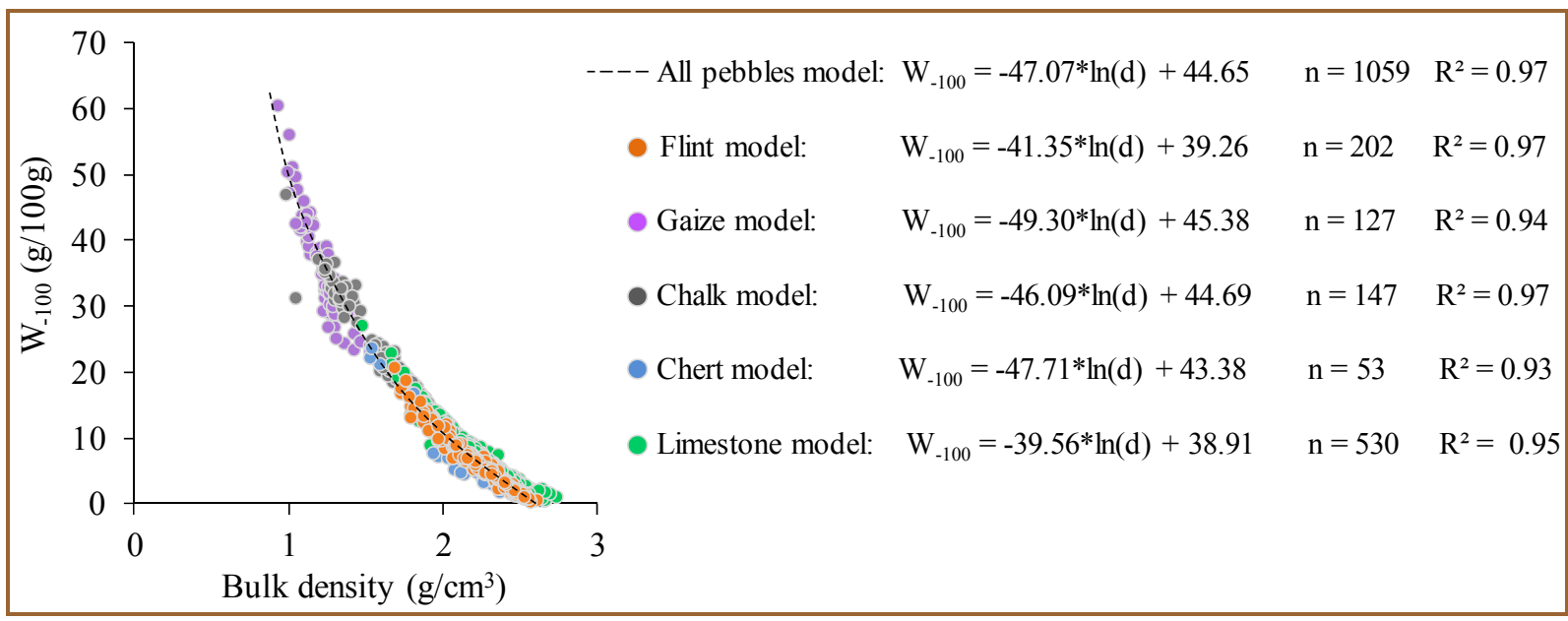

Figure 8: Relationship between water content at $-100 \mathrm{hPa}\left(\mathrm{W}_{-100}\right)$ and bulk density. $R^{2}$ is the determination coefficient and $\mathbf{n}$ is the number of samples analysed. 


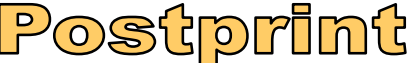

Version définitive du manuscrit publié dans / Final version of the manuscript published in : Geoderma, 165(1), 40-45

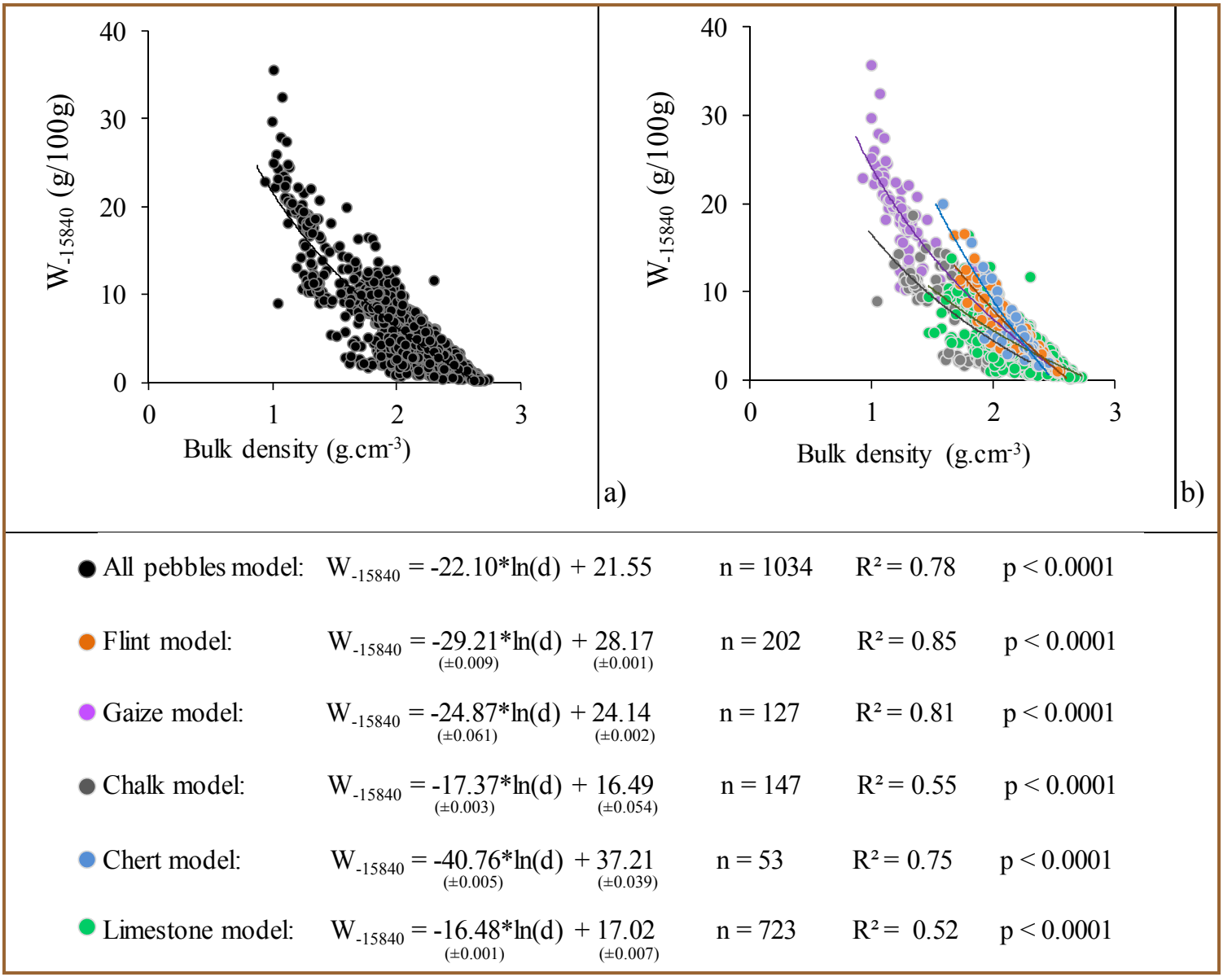

Figure 9: Relationship between water content at $-15840 \mathrm{hPa}\left(\mathrm{W}_{-15840}\right)$ and bulk density. a) General relationship. b) Specific relationships by pebbles lithological class. $R^{2}$ is the determination coefficient and $\mathbf{n}$ is the number of samples analysed.

The comparison of the specific and general relationships for equation (6) showed that the gravimetric water content at $-100 \mathrm{hPa}\left(W_{-100}\right)$ can be correctly estimated from the bulk density by using the general relationship (coefficient $a_{1}$ and $\mathrm{b}_{1}$ of Eq. 6). On the contrary, the gravimetric water content at $-15840 \mathrm{hPa}\left(W_{-15840}\right)$ is better estimated by the specific relationships (Eq. 7).

Nevertheless, flint rock fragments represent an exception: for a range of bulk density comprised between 1.68 and $2.05 \mathrm{~g} \mathrm{~cm}^{-3}$, their gravimetric water content at $-100 \mathrm{hPa}$ can then be estimated by two types of equation Eq. (6), with the same slope, but with a shift of 9.6 $\mathrm{g} / 100 \mathrm{~g}$ in water content (Fig. 10). This difference has to be taken into account for calculation of the available water content of flint rock fragments using bulk density. Due to the variable age of the flint used in this study (Table 1), it may be related to the degree of weathering of the rock fragments, as already stated by Poesen and Lavee (1994) and Cuniglio et al. (2009). 
Version définitive du manuscrit publié dans / Final version of the manuscript published in :

Geoderma, 165(1), 40-45

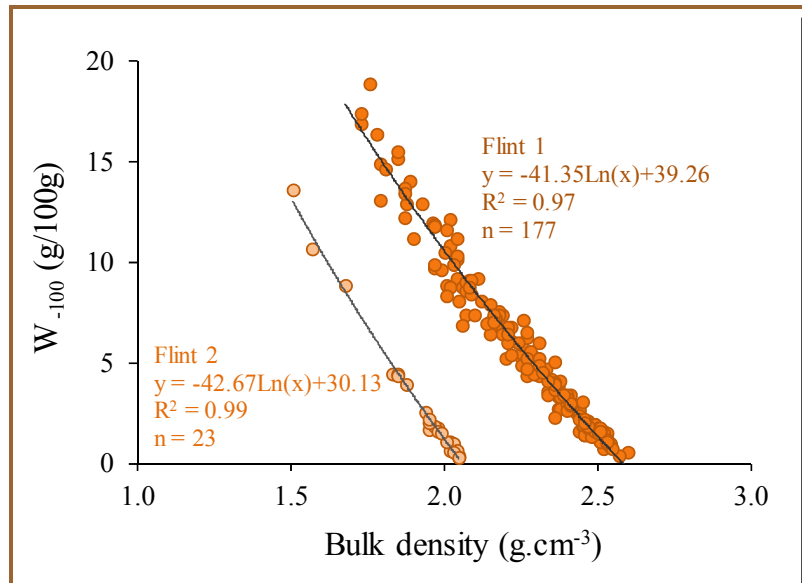

a)

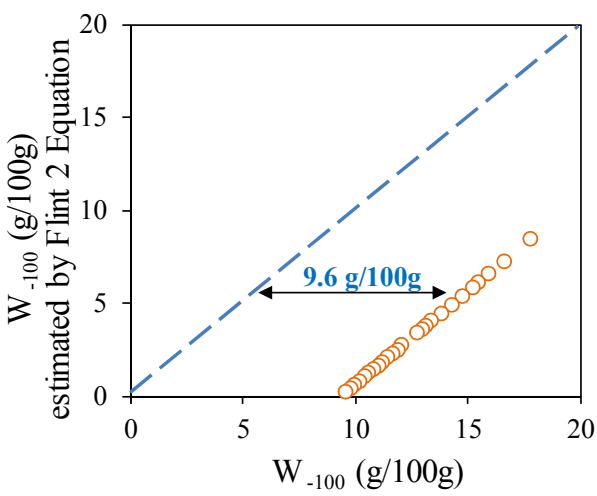

estimated by Flint 1 Equation

Figure 10: a) Relationship between water content at $-100 \mathrm{hPa}\left(\mathrm{W}_{-100}\right)$ and bulk density for flint rock fragments. The two equations defined (Flint 1 and Flint 2 ) are represented. For each equation, $R^{2}$ is the determination coefficient and $\mathbf{n}$ is the number of samples analysed. b) Relationship between water content at $-100 \mathrm{hPa}\left(\mathrm{W}_{-100}\right)$ estimated by Flint 1 equation (x-axis) and Flint 2 equation (y-axis). The shift of 9.6 $\mathrm{g} / 100 \mathrm{~g}$ in gravimetric water content between the two equations is represented.

From these equations, it is therefore possible to estimate the available water content of pebbles by using only the dry bulk density. From equations (Eq. 6) and (Eq. 7), we defined the following pedotransfer function:

Erreur ! Signet non défini. $A W C=a_{3} \ln (d)+b_{3}$

where $a_{3}$ and $b_{3}$ are parameters whose values depend on the lithology of pebbles (Table 3). This equation is relevant only for bulk densities less than or equal to $2.5 \mathrm{~g} \mathrm{~cm}^{-3}$. Beyond this value, the AWC of rock fragments must be considered equal to zero. Bulk densities of pebbles and gravels have been shown to be in the same range. We then hypothesize that they exhibit the same water properties and, for that reason, the estimation of AWC in pebbles by equation Eq. (8) can be extended to gravels.

Table 3: The fitting parameters $a_{1}, a_{2}, a_{3}\left(\mathrm{~cm}^{3} / 100 g\right)$ and $b_{1}, b_{2}, b_{3}(g / 100 g)$ of the equations (Eqs. 1.6, 1.7, 1.8). $\mathbf{n}$ is the number of samples. $R^{2}$ is the coefficient of determination.

\begin{tabular}{l|c|ccc|ccc|cc}
\hline \multicolumn{2}{c|}{ Pebbles } & \multicolumn{3}{c|}{$W_{-100}=a_{1} \ln (d)+b_{1}$} & \multicolumn{2}{c|}{$W_{-15840}=a_{2} \ln (d)+b_{2}$} & \multicolumn{2}{c}{$A W C=a_{3} \ln (d)+b_{3}$} \\
\hline Type & $\mathrm{n}$ & $a_{1}$ & $b_{1}$ & $R^{2}$ & $a_{2}$ & $b_{2}$ & $R^{2}$ & $a_{3}$ & $b_{3}$ \\
\hline Flint & 177 & -41.35 & 39.26 & 0.97 & -29.21 & 28.17 & 0.85 & -12.14 & 11.09 \\
Gaize & 127 & -49.30 & 45.38 & 0.94 & -24.87 & 24.14 & 0.81 & -24.43 & 21.24 \\
Chalk & 147 & -46.09 & 44.69 & 0.97 & -17.37 & 16.49 & 0.55 & -28.72 & 28.20 \\
Chert & 53 & -47.71 & 43.38 & 0.93 & -40.76 & 37.21 & 0.75 & -6.95 & 6.17 \\
Limestone & 530 & -39.56 & 38.91 & 0.95 & -16.48 & 17.02 & 0.52 & -23.08 & 21.89 \\
All & 1564 & -47.07 & 44.65 & 0.97 & -22.10 & 21.55 & 0.78 & -24.97 & 23.10 \\
\hline
\end{tabular}

\subsection{Estimation of the soil available water content (SAWC) at the horizon scale}

From equation Eq. (8), we can estimate the role of rock fragments in the total soil available water content $(S A W C)$ for a stony horizon, as defined here by the volume of water 


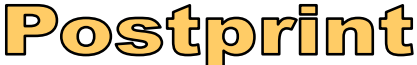

Version définitive du manuscrit publié dans / Final version of the manuscript published in :

Geoderma, 165(1), 40-45

(expressed in millimeters) that is available for plants. By considering the same distribution of bulk density for pebbles and gravels (Fig. 3), we thus assumed that gravels and pebbles have the same hydric properties. The $S A W C$ of a stony horizon was therefore calculated using the equation proposed by Cousin et al. (2003) :

$$
S A W C=\sum_{i} A W C_{i} \cdot p i
$$

where $A W C_{i}$ represents the available water content of the phase $i, p i$ represents the volumetric proportion of the phase $i$, when $i$ means either "rock fragments" or "fine earth".

To estimate the role of the rock fragments in the $S A W C$, we performed a theoretical calculation. As an example, let us suppose a $30 \mathrm{~cm}$ thick horizon, comprised of fine earth and rock fragments in different volumetric proportions. The fine earth has a loamy clay texture, with a dry bulk density of $1.3 \mathrm{~g} \mathrm{~cm}^{-3}$. Its $A W C$ was here estimated using the pedotransfer class of Bruand et al. (2004) and was equal to $0.14 \mathrm{~cm}^{3} . \mathrm{cm}^{-3}$. The contribution of the rock fragment to the $S A W C$ is calculated according to equation Eq. (8) for different lithologies, considering the mean value of bulk density of the different lithologies of rock fragments. Without any rock fragment, the $S A W C$ of this loamy clay horizon is estimated to $55 \mathrm{~mm}$. Considering that the rock fragments contain water, the $S A W C$ can decrease or increase depending on the lithology of the rock fragments (Fig. 11). Whatever the percentage of rock fragments in soil, we notice that, i) the $S A W C$ of soils containing flint, chert or limestone is always overestimated when soil is considered to be constituted only by fine earth, ii) the $S A W C$ of soils with chalk is always underestimated, and those of soils with gaize has a very low overestimation under the same hypothesis (Fig. 11a). For example, with 30\% rock fragments (respectively $70 \%$ ), the $S A W C$ may be overestimated by $35.6 \%$ for chert rock fragments (respectively $157.8 \%$ ) and may be underestimated by $4.3 \%$ for chalk rock fragments (respectively 9.4\%).

Whatever the lithology of the rock fragments, one can then underestimate the SAWC when neglecting the ability of the rock fragments to store water (Fig. 11b). For example, with $30 \%$ rock fragments (respectively 70\%), this underestimation may be $5.1 \%$ for chert rock fragments (respectively $22.7 \%$ ) and $33 \%$ for chalk rock fragments (respectively $72.8 \%$ ). By neglecting the rock fragments in the calculations of the $S A W C$ at the horizon scale, the $S A W C$ can be overestimated or underestimated depending of the lithology of the rock fragment. 


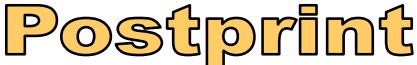

Version définitive du manuscrit publié dans / Final version of the manuscript published in :

Geoderma, 165(1), 40-45

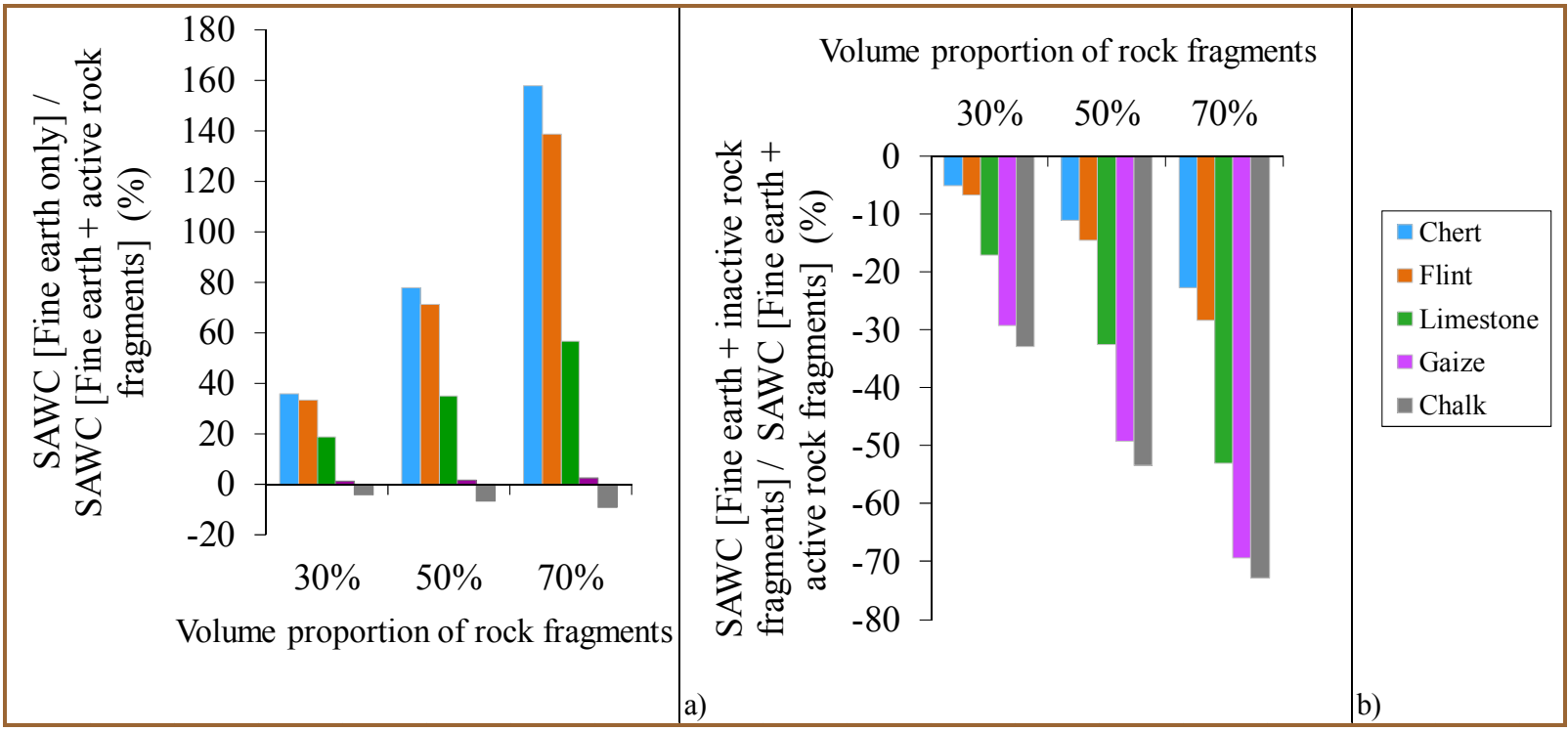

Figure 11: Variations in Soil Available Water Content (SAWC) depending on both the lithological class and the volume proportion of rock fragments. a) Calculation of the SAWC when the horizon is composed of fine earth only, compared to the SAWC calculated when the horizon is composed of both fine earth and rock fragments containing water. b) Calculation of the SAWC when the horizon is composed of fine earth and rock fragments supposed to be non-porous, compared to the SAWC calculated when the horizon is composed of both fine earth and rock fragments containing water.

\subsection{Consequences in terms of samplings of stony soils}

To estimate the contribution of the rock fragments to the $S A W C$ of a stony horizon as stated in equation Eq. (9), only two informations about the rock fragments are required:

1- the dry bulk density of the rock fragments, that enables to calculate the AWC of the stony phase. As far as small differences in bulk density of rock fragments may exist in a given horizon, we recommend collecting at least a set of 12 rock fragments; their mean bulk density can then be simply estimated by measurements using the Archimedes' displacement method with kerosene (Monnier et al., 1973).

2- the volumetric proportion of rock fragments in the horizon. This point remains the most critical one for the estimation of the $S A W C$ at the horizon scale, because an error in the volumetric proportion of rock fragments would lead to strong bias of the $S A W C$. For a surface horizon, the proportion could be estimated by image analysis from remote sensing data, but overestimations of the actual rock fragments content could occur when data are obtained after a rain, as well as underestimations could occur when data are obtained after ploughing (Girard and Girard, 2003; Scanvic, 1983). For deeper horizons, this proportion remains hard to determine, and would require digging large soil pits. 
Version définitive du manuscrit publié dans / Final version of the manuscript published in :

Geoderma, 165(1), 40-45

\section{Conclusions}

The main objective of this work was to better understand the contribution of the rock fragments to the $S A W C$ of stony soils. The bulk density, the solid density and the gravimetric water content at different water potentials were characterized on pebbles and gravels from stony soils developed on sedimentary rocks of varying lithological classes: flint, gaize, chalk, chert, and limestone. Whatever the lithology, data indicated that the rock fragments did not store water above field capacity (equivalent here to $-100 \mathrm{hPa}$ and saturation), because the voids of the pebbles were completely filled by water at field capacity. We also demonstrated that the water content at the wilting point could be expressed in terms of water content at -100 $\mathrm{hPa}$ or saturation. To assess the contribution of the rock fragments to the SAWC of a stony horizon, we proposed two pedotransfer functions estimating the AWC of rock fragments, which take into account only their water content at $-100 \mathrm{hPa}\left(A W C \approx \xi W_{-100}+\varsigma\right)$, or their bulk density $\left(A W C=a_{3} \ln (d)+b_{3}\right)$. The $\xi, \varsigma, \mathrm{a}_{3}$ and $\mathrm{b}_{3}$ parameters depend only on the lithology of the rock fragments. Nevertheless, to avoid bias of the SAWC of a stony horizon, we recommend a good characterisation of i) the bulk density of rock fragments by a representative sampling of the soil horizon and ii) the volume proportion of the rock fragments.

In a future work, these pedotransfer functions could be used to map the SAWC of stony soils over large areas.

\section{References}

Baetens, J.M., Verbist, K., Cornelis, W.M., Gabriels, D. and Soto, G., 2009. On the influence of coarse fragments on soil water retention. Water Resources Research, 45.

Ballif, J.L., 1978. Porosité de la craie, Appréciation de la taille et de la répartition des pores. Annales Agronomiques, 29: 123 -131.

Berger, E., 1976. Partitioning the parameters of stony soils, important in moisture determinations in to their constituents. Plant Soils, 44: 201-207.

Brakensiek, D.L. and Rawls, W.J., 1994. Soil containing rock fragments: effects on infiltration. Catena, 23: 99-110.

Bruand, A., Duval, O. and Cousin, I., 2004. Estimation des propriétés de rétention en eau des sols à partir de la base de données SOLHYDRO: Une première proposition combinant le type d'horizon, sa texture et sa densité apparente. Étude et Gestion des Sols, 11(3): 323-334.

Bruand, A., Duval, O., Gaillard, H., Darthout, R. and Jamagne, M., 1996. Variabilités des propriétés de rétention en eau des sols: importance de la densité apparente. Étude et Gestion des Sols, 3(1): 27 - 40. Childs, S. and Flint, A.L., 1990. Physical properties of forest soils containing rock fragments. In Sustained productivity of forest soils. Weetman, R.F. Powers
(Editor), University of British Columbia, Vancouver, pp. 95-121.

Coile, T.S., 1953. Moisture content of small stone in soils. Soil Science, 75: 203-207.

Corey, A.T. and Kemper, W.D., 1968. Conservation of soil water by gravel mulches. Hydrological Paper $n^{\circ}$ 30. Colorado State University, FT Collins.

Corti, G., Ugolini, F.C. and Agnelli, A., 1998. Classing the soil skeleton (greater than two millimeters): Proposed approach and procedure. Soil Science Society of America Journal, 62(6): 1620-1629.

Cousin, I., Nicoullaud, B. and Coutadeur, C., 2003. Influence of rock fragments on the water retention and water percolation in a calcareous soil. Catena, 53(2): 97.

Coutadeur, C., Cousin, B. and Nicoullaud, B., 2000a. Influence de la phase caillouteuse sur la réserve en eau des sols. Cas des sols de Petite Beauce du Loiret. Étude et Gestion des Sols, 7(3): 191-205.

Coutadeur, C., Cousin, B. and Nicoullaud, B., $2000 \mathrm{~b}$. Influence de la phase caillouteuse sur la réserve en eau des sols. Cas des sols de Petite Beauce du Loiret. Etude et Gestion des Sols, 7(3): 191-205.

Cuniglio, R., Corti, G. and Agnelli, A., 2009. Rock fragments evolution and nutrients release in vineyard 


\section{옘ㄷำ}

Version définitive du manuscrit publié dans / Final version of the manuscript published in :

Geoderma, 165(1), 40-45

soils developed on a thinly layered limestone (Tuscany, Italy). Geoderma, 148(3-4): 375-383.

FAO, 2006. Guidelines for soil description, Rome, 109 pp.

Foucault, A., Raoult, J-F., 2001. Dictionnaire de géologie. 5e Edition. Dunod. Paris, 379 pp.

Fies, J.C., Louvigny, N.D.E. and Chanzy, A., 2002. The role of stones in soil water retention. European Journal of Soil Science, 53(1): 95-104.

Girard, M.C., Girard, C.M., 2003. Traitement de données de télédétection. Editions Dunod. Paris, 527 pp.

Grant, J.W. and Struchtemeyer, R.A., 1959. Influence of coarse fraction in two Maine potato soils on infiltration, runoff and erosion. Soil Science Society of America Proceedings, 23: 391-394.

Gras, R., 1994. Sols caillouteux et production végétale, Paris, 175 pp.

Gras, R. and Monnier, G., 1963. Contribution de certains éléments grossiers à l'alimentation en eau des végétaux. Science du Sol, 1: 13-20.

Groenevelt, P.H., Straaten, P., Rasiah, V. and Simpson, J., 1989. Modification in evaporation parameters by rock mulches. Soil Technology, 2: 279-285.

Jury, W.A. and Bellantuoni, B., 1976. Heat and water movement under surface rocks in a field soil: II. Moisture effects. Soil Science Society of America Journal, 40(509-513).

Kemper, W.D., Nick, A.D. and Corey, A.T., 1994. Accumulation of water in soils under gravel and sand mulches. Soil Science Society of America Journal, 58: 56-63.

Klute, A., 1986. Methods of Soil Analysis, Part 1, Physical and Mineralogical properties. In: Agronomy (Editor), Madison, Wisc., USA. Amer., Society.

Koon, J.L., Hendrick, J.G. and Hermanson, R.E., 1970. Some effects of surface cover geometry on infiltration rate. Water Resources Research, 6: 246-253.

Ma, D., Shao, M., Zhang, J. and Wang, Q., 2010. Validation of an analytical method for determining soil hydraulic properties of stony soils using experimental data. Geoderma, 159(3-4): 262.

Ma, D.H. and Shao, M.G., 2008. Simulating infiltration into stony soils with a dual-porosity model. European Journal of Soil Science, 59(5): 950-959.

Michel, J-P., Carpenter, M.S.N., Fairbridge, R.W., 2004. Dictionnaire des sciences de la terre.

Anglais/français - Français/Anglais. 4e Edition. Dunod. Paris, 398 pp.

Monnier, G., Stengel, P. and Fiès, J.C., 1973. Une méthode de mesure de la densité apparente de petits agglomérats terreux. Application à l'analyse des systèmes de porosité du sol. Annales Agronomiques, 24(5): 533-545.

Poesen, J. and Bunte, K., 1996. The Effects of Rock Fragments on Desertification Processes in Mediterranean Environments. In: C.J. Brandt and J.B. Thornes (Editors), Mediterranean Desertification and Land Use. Wiley, Chichester, pp. 247- 267.

Poesen, J. and Lavee, H., 1994. Rock fragments in top soils: significance and processes. Catena, 23: 1-28.

Ravina, I. and Magier, J., 1984. Hydraulic conductivity and water retention of clay soils containing coarse fragments. Soil Science Society of America Journal, 48(736-740).

Scanvic, J.Y., 1983. Utilisation de la télédétection dans les sciences de la terre, Orléans, BRGM, Col. : Manuels et méthodes $\mathrm{n}^{\circ} 7,158 \mathrm{pp}$.

Soil Survey Staff, 2010. Keys to Soil Taxonomy. In: U.S.D.A.-N.R.C. Service (Editor), Washington, DC., pp. 346.

Ugolini, F.C., Corti, G., Agnelli, A. and Certini, G., 1998. Under- and overestimation of soil properties in stony soils, 16th World Congress of Soil Science, Montpellier, France.

Urbanek, E. and Shakesby, R.A., 2009. Impact of stone content on water movement in water-repellent sand. European Journal of Soil Science, 60(3): 412-419.

Vachier, P., Cambier, P. and Prost, R., 1979. Structure d'un milieu poreux: la craie. Annales agronomiques, 30(3): $247-263$

Van Wesemael, B., Poesen, J., Kosmas, C.S., Danalatos, N.G. and Nachtergaele, J., 1996. Evaporation from cultivated soils containing rock fragments; Journal of Hydrology 182, 65-82.

Verbist, K. et al., 2009. Hydraulic conductivity as influenced by stoniness in degraded drylands of Chile. Soil Science Society Of America Journal, 73(2): 471484.

Zhou, B.B., Shao, M.A. and Shao, H.B., 2009. Effects of rock fragments on water movement and solute transport in a Loess Plateau soil. Comptes Rendus Geoscience, 341(6): 462-472. 